\title{
A Study of the Factors Affecting the Choice of Investment Portfolio by Individual Investors in Singapore
}

\author{
A.Seetharaman ${ }^{1}$, Indu Niranjan ${ }^{2}$, Nitin Patwa $^{3} \&$ Amit Kejriwal $^{4}$ \\ ${ }^{1}$ Dean Academic Affairs, S P Jain School of Global Management - Dubai - Mumbai - Singapore - Sydney \\ ${ }^{2}$ Dean, GMBA Program, S P Jain School of Global Management - Dubai - Mumbai - Singapore - Sydney \\ ${ }^{3}$ Director of Simulations, S P Jain School of Global Management - Dubai - Mumbai - Singapore - Sydney \\ ${ }^{4}$ Post-Graduate Scholar, S P Jain School of Global Management - Dubai - Mumbai - Singapore - Sydney \\ Correspondence: Nitin Patwa, S P Jain School of Global Management - Dubai - Mumbai - Singapore - Sydney
}

Received: May 31, 2017

Accepted: June 14, 2017

Online Published: August 21, 2017

doi:10.5430/afr.v6n3p153

URL: https://doi.org/10.5430/afr.v6n3p153

\begin{abstract}
Singapore being an island economy and a financial hub with residents from diverse backgrounds, huge ethnic diversity, coming from different part of the world. This study aims to gain insights and information into the factors that affect investment planners, financial advisers and individuals need to consider improving their choice of the portfolio and its performance. People's investment decisions and hence their portfolio, which hitherto has not been tested. Furthermore, it intends to identify the factors that drive investors to choose one investment over another and determine how they make their investment portfolios. The survey was modelled using the smart-pls statistical package (PLS-SEM), which is partial least squares structural equation modelling.
\end{abstract}

Keywords: Investment portfolio, Financial investment, Investment Decisions

\section{Introduction}

This study investigates the factors that determine and affect the investment portfolio of individual investors in Singapore. To employ the funds for a period to enhance one's wealth can be distinctively categorised between real and financial investment. Investment into the land, building, machinery etc i.e. tangible asset is termed as a real investment vs investment in stocks and bond as a financial investment. Our research focuses on financial investment more accurate to purchase a financial product or another item of value with an expectation of favourable future returns

Virtually everyone makes investments. Investors today have some options to choose from to deposit their savings. Hence it becomes imperative to analyse investment process and investment management decision making in the substantially broader context (Peñaranda, 2016). Every investor has objectives, often not designed very prudently. When objectives are not clearly and consciously articulated, investors may land up making a decision which gives a suboptimal return. It is therefore wise to clarify investment objectives, to gain a clear understanding of what the portfolio is intended to accomplish. Even if an investor is unable to define investment objectives and procedures in a written Investment Policy Statement, they enhance their chances of achieving a positive result if they adopt a rational and a prudent investment approach. An investor may have a short term or a long term horizon; the short-term effectiveness examined through the event analysis of the abnormal return for the recommended stock around the financial announcement or due to market fluctuations whereas long-term investment horizon examined through the investment value from a passive portfolio management strategy (Tao, 2010). While investing, a systematic process is needed to reduce the risk, and eliminate to the extent possible, the detrimental effect that emotion, behaviour, and excessive fees and taxes have on overall investment performance while also specifying how investment opportunities and investment managers will be identified (Pfeiffer, 2016). The risk and returns available from each of different investment avenues differ. Even if an individual does not select specific assets, such as stock, investments still happen through participation in mandatory government pension plans and employee saving programmes or the purchase of life insurance or a home, according to Tamil Selvi (2015).

The different avenues of investment areas are as follows:

i. Low-risk avenues: savings accounts, bank fixed deposits, CPF, government securities and so on.

ii. Moderate-risk avenues: mutual funds, unit trusts, ETF, life insurance, debentures, bonds. 
iii. High-risk avenues: equity share market, commodity market, FOREX market.

iv. Traditional avenues: real estate (property), gold/silver.

v. Emerging avenues: virtual real estate, hedge funds/private equity investments, art and passion.

Investors choose an appropriate avenue depending on their specific need, risk preference and expected returns. Harry Markowitz (1952) in his paper "Portfolio Selection," (published in 1952 by the Journal of Finance) created the modern portfolio theory, which assumes that investors are rational and tend to create optimal portfolios that offer the maximum possible expected return for a given level of risk. There is, however, another theory that has also been accepted. It is the behavioural finance theory, which explains the understanding of the logical patterns of investors, including the psychological processes and the extent to which the decision-making process is influenced (Ricciardi and Simon, 2000). Ideally, behavioural finance explains the "what", "why" and "how" of funding and investment.

Singapore is an island economy and a financial hub with residents from diverse backgrounds coming from all over the world, such as Europe, Australia, America and other parts of Asia, our objective was to study:

\subsection{Objectives of Research}

1. Identify factors that affect people's investment decisions and hence their portfolio, which hitherto have not been tested.

2. To determine the factors that drive investors to choose one investment over another and determine how they make their investment portfolios.

\section{Review of the Literature and Research Structure}

The existing literature identifies the driving factors affecting individual portfolios mainly in developing countries.

\subsection{Investment Objective}

A wide choice of investments is available today, but these can be categorised broadly according to three fundamental characteristics - safety, income and growth - which also correspond to the types of investor objectives. According to Hoffmann, Shefrin and Pennings (2010), investors whose primary investment objective is to build a financial buffer or save for retirement have lower aspirations.

\subsubsection{Investment Time Horizon}

Veld-Merkoulova (2009) stated that a longer investment horizon leads to an increasing share of risky financial investments, regardless of investors' age. The findings of Fagereng, Gottlieb and Guiso (2015) from research conducted in Norway showed that people tend to enter the stock market early in life as they accumulate assets and invest a greater share of their wealth in stocks. As they approach retirement, they adjust their portfolio, reducing it gradually.

\subsubsection{Income Level}

Praba (2011) conducted a study aiming to understand how the saving objectives of individuals relate to the investment avenue. It is observed that investors' major saving objectives are wealth maximisation, contingency management and children's welfare. Different factors, like age, gender, profession and annual income, also determine the investment objective of individuals. Jain and Mandot (2012) also studied the impact of demographic factors on the investment decision of investors in Rajasthan, concluding that various demographic factors, like age, marital status, gender, city, income level, market knowledge, occupation and qualifications, have a major impact on the investment decision of investors.

\subsubsection{Life Cycle Stages}

According to the findings of Shah, Zanwar, and Deshmukh (2011), the lifecycle stages have a significant relationship with the investment avenues, objectives behind the investment, sources of information and guiding factors of investment. Maheswari (2014) stated that there is a significant correlation between the age of the investor and the financial planning. An ANOVA test showed that there is the difference in the perception of planning by investors in different age groups.

H1. Individuals' investment objective has a direct effect on their behaviour and thereby affects their choice of the portfolio. 


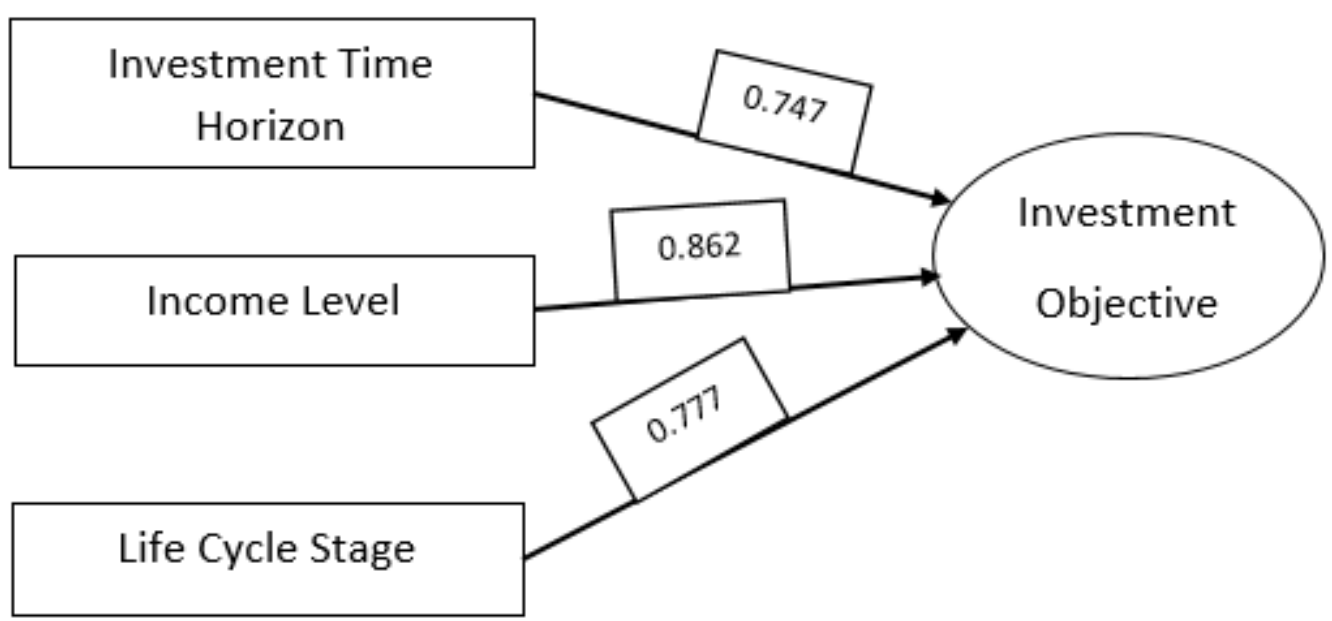

In the above SEM model of the path coefficients for the individual constructs, namely the investment time horizon (0.747), income level (0.862) and life cycle stage (0.777), the path for the income level is above 0.8, which signifies a strong effect on the independent variable. The path coefficients of 0.747 and 0.777 for the investment time horizon and lifecycle stage, respectively, are in the range of 0.5 to 0.8 and therefore depict a moderate effect on these independent variables.

\subsection{Risk Profile}

Cohn, Lewellen, Lease and Schlarbaum (1975) attempted to investigate empirically the effect of wealth on the proportions of individual portfolios allocated to risky assets. They found a strong pattern of decreasing relative risk aversion; that is, as wealth increases, people tend to invest more in riskier assets.

Nosic and Weber (2010) stated that risk-taking behaviour in an investment context is affected by individual risk attitudes, risk perceptions and return expectations. Behavioural biases, such as overconfidence and excessive optimism, significantly affect risk behaviour.

\subsubsection{Risk Attitude}

Siebenmorgen and Weber (2004) studied the effect of different investment horizons on risk perception, expected returns and portfolio choice. They found that people have different short-term and long-term risk perceptions and hence the short- and total long-term portfolio risk that participants are willing to take differs.

The portfolios of investors with above-median risk profiles have greater exposure to risky investments (Hoffmann et al., 2010). From the findings of Pandit and Yeoh (2014), it is apparent that the greater an investor's risk propensity, the less likely it is that he/she will postpone purchases of shares or investments.

\subsubsection{Expected Return for the Given Risk}

According to the findings of Baker, Hargrove and Haslem (1977), the positive association between risk and expected return appears to be due to the impact of capital appreciation on investors' expectations of total returns. As shown by Frijns, Koellen and Lehnert (2006), an increase in the risk-return trade-off (a larger return for a given amount of risk) enhances the demand for risky assets.

\subsubsection{Risk Tolerance}

Örerler and Taşpınar (2006) stated that in general there is lower risk tolerance for the unknown since the impacts are new, unobservable or delayed. Higher risk tolerance emerges when people feel more in control. Risk tolerance can be determined through consultation with affected parties or by assessing investors' response or reaction to varying levels of risk exposure. Risk tolerance may change over time as new information and outcomes become available or as societal expectations evolve (Evans, 2004). Investors should explore the connections, or lack thereof, between their risk tolerance profiles and their expectations of investment returns. Finally, those attributes should be made explicit and used as key inputs in structuring their portfolios. 
H2. Individuals' risk profile has a direct effect on their investment behaviour and thereby affects their choice of the portfolio.

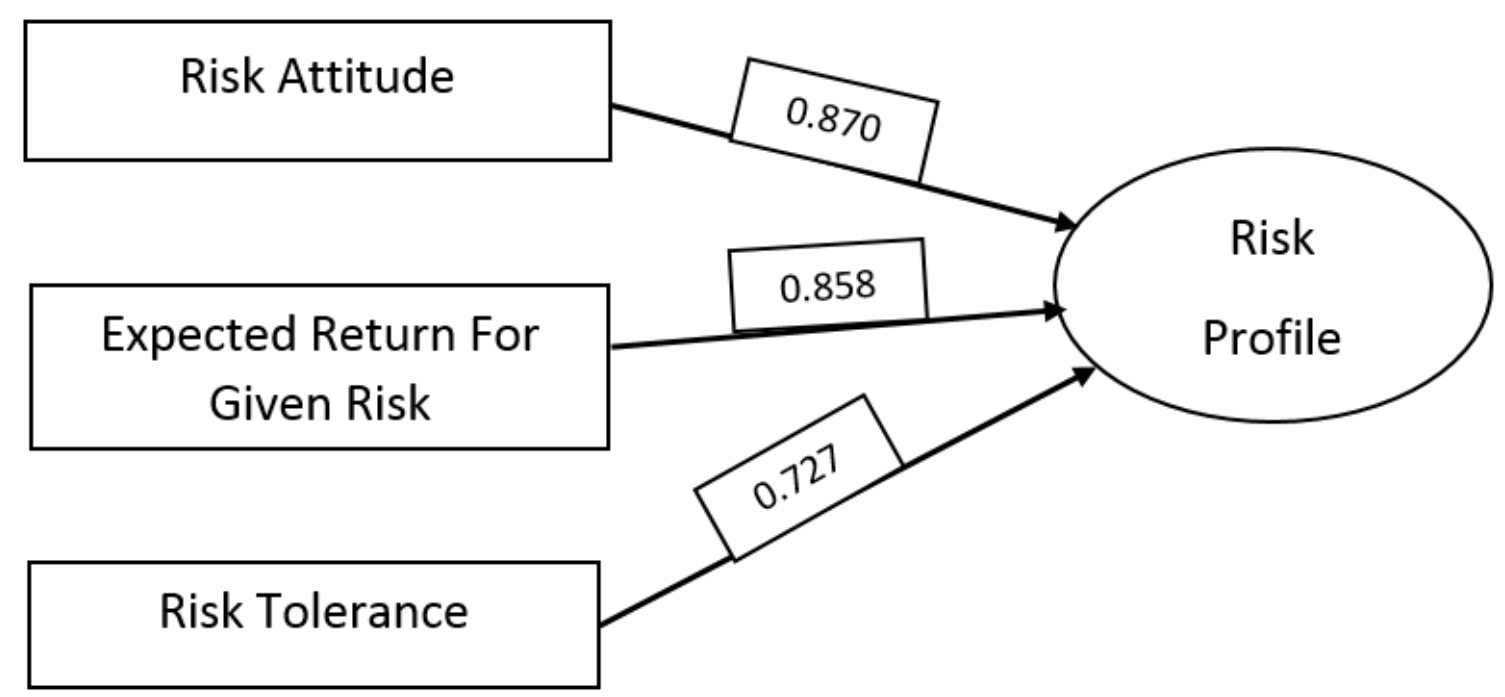

In the above SEM model of the path coefficients for the individual constructs, namely the risk attitude (.870), expected return for given risk (0.858) and risk tolerance (.727), the paths for the risk attitude and expected return for the given risk is above 0.8. This shows a strong effect on the independent variable, while the path coefficient of .727 for risk tolerance, which is in the range of 0.5 to 0.8 , depicts a moderate effect on the independent variable.

\subsection{Asset Familiarity}

According to the findings of Sahi, Arora and Dhameja (2013), people tend to develop a strong liking for certain investments just because they are familiar with them. This makes them feel as if they have more knowledge or experience about such investment products and thus they gain a sense of comfort and security. However, Frijns, Koellen and Lehnert (2006) found no clear evidence of asset familiarity on investors' investment behaviour and portfolio choices.

\subsubsection{Financial Knowledge}

Hibbert, Lawrence and Prakash (2012) stated that individuals who have more knowledge of finance are more likely to allocate the majority of their investments efficiently. Finance professors are significantly more likely to invest in foreign stock/bonds or foreign mutual funds and more likely to manage their retirement savings portfolios actively.

\subsubsection{Investment Products Available in the Native Market}

Lindblom, Mavruk and Sjögren (2013) says that the average investor's proximity bias grows stronger as the longer the investor has lived within the same community. It gets stronger for investors who have never moved from their birthplace area. Local investors have neither access to superior information nor any advantage in interpreting the existing information.

\subsubsection{Familiar Investment Products}

According to the findings of Foad (2010), there are multiple explanations for familiarity bias. Behavioural explanations suggest that investors fail to assess the risk of company stock accurately, perhaps due to overconfidence in predicting the returns of familiar assets, preferring local assets to avoid regret. Sahi, Arora and Dhameja (2013) stated that people tend to develop a strong liking for certain investments just because they are familiar with them.

\subsubsection{Patriotism and Social Identification}

Foad (2010) asserted that people view familiar assets more favourably due to patriotism and social identification. As a result of familiarity bias, people do not diversify and hold suboptimal portfolios. However, greater diversification could generate higher returns and lower risk.

H3. Individuals' asset familiarity has a direct effect on their behaviour and thereby affects their choice of the portfolio. 


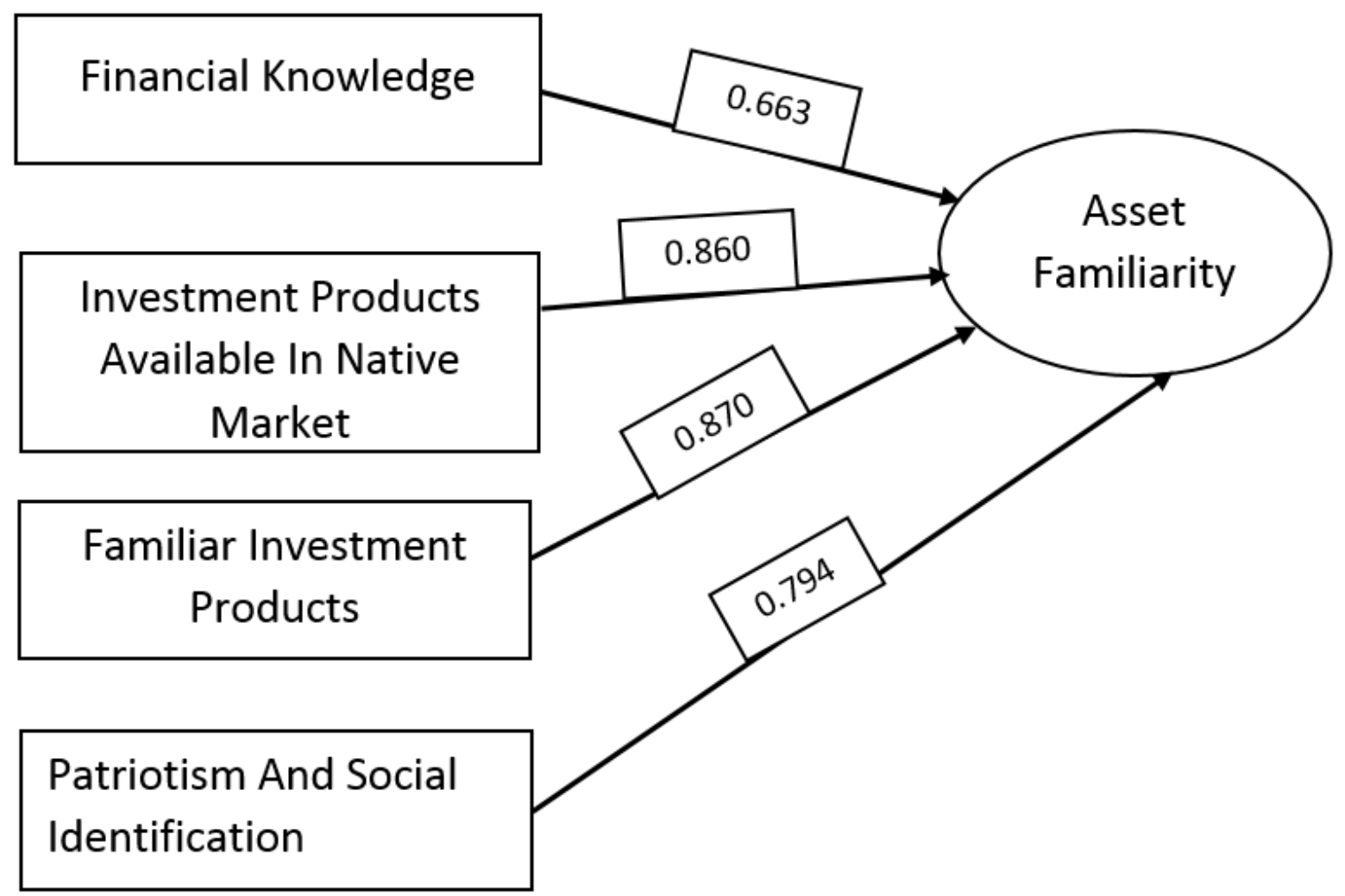

In the above SEM model of the path coefficients for the individual constructs, namely financial knowledge (.663), investment products available in the native market (0.860), familiar investment products (.870) and a feeling of patriotism and social identification (.794), those with knowledge of products available in the native market and familiar investment products are above 0.8 , which signifies a strong effect on the independent variable. However, some of the constructs are between 0.5 and 0.8 , namely financial knowledge and a feeling of patriotism and social identification, which shows a moderate effect on the independent variable.

\subsection{Investor Behaviour}

From Peteros and Maleyeff's (2013) study, it can be seen that investors' portfolios underperform due to irrational (biased) decision making. The action is taken based on behaviour that reflects recent investment returns is counterproductive in all cases.

Mohamed, Hachicha and Bouri (2012) demonstrated that the mean-variance theory (Markowitz, 1952) affirms that investors are rational enough to maximise their utility function. However, with the emergence of behavioural finance, the domain of portfolio management should integrate new dimensions, such as investors' psychology (Kahneman and Tversky, 1979). The theory, based on behavioural aspects, asserts that psychology and emotions affect the decision-making of investors and are interrelated in their cognitive schema. Their results showed the existence of complementarities between the rational and the behavioural theories of portfolio choice since the average cognitive map demonstrates the presence of both technical concepts and other behavioural concepts. They used the mean-variance technique and stated that individuals' behaviour would get moderated by their emotions and psychological state.

\subsubsection{Market Sentiments}

In Frijns, Koellen and Lehnert's (2006) research on the behavioural model shows that investors are more influenced by market sentiments (they invest more in risky assets) under bullish sentiments than under bearish sentiments. Secondly, investors with a higher level of self-assessed financial expertise (taken as a proxy for overconfidence) prefer risky assets.

\subsubsection{Expected Returns}

According to the findings of Baker, Hargrove and Haslem (1977), the positive association between risk and expected return appears to be due to the impact of capital appreciation on investors' expectations of total returns. 


\subsubsection{Past Experience}

Cohen and Kudryavtsev (2012) indicated that past experiences in the capital market (such as a gain or loss in stocks) and knowledge about the past performance of selected market indices influence future investment decisions.

Durand, Newby, Peggs and Siekierka (2013) argued that investors' personalities get associated with theory investment choices; some investors prefer tried and tested products while others opt for innovative investment products.

H4. Individuals' investment behaviour has a direct effect on their choice of the portfolio and its performance.

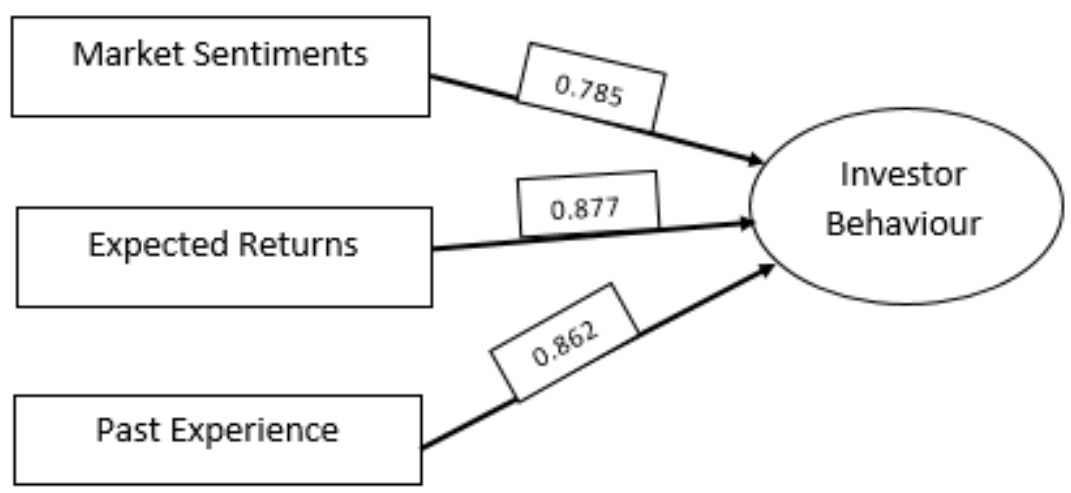

In the above SEM model of the path coefficients for the individual constructs, namely market sentiments (.785), expected returns $(0.877)$ and experience (.862), those with experience and expected returns are above 0.8 , showing a strong effect on the independent variable. Meanwhile, the path coefficient of .785 for market sentiments, which is in the range of 0.5 to 0.8 , depicts a moderate effect on the independent variable.

H5. The impact of the investment objective on the choice of the portfolio is mediated by the perceived extent of investment behaviour.

H6. The impact of the risk profile of the choice of the portfolio is mediated by the perceived extent of investment behaviour.

H7. The impact of asset familiarity on the choice of the portfolio is mediated by the perceived extent of investment behaviour.

\section{Research Methodology}

The research was conducted and insights were captured using both primary data, namely surveys, questionnaires and so on, and secondary data, that is, a thorough review of journals.

The secondary data were collected through a literature review of articles, leading to the identification of the independent variables argued to affect investors' behaviour, their choice of the portfolio and its performance. The primary data were collected through an online questionnaire conducted with a sample population of individuals who hold an investment portfolio. The dependent and independent variables were identified and their relationship is shown in the diagram below. 


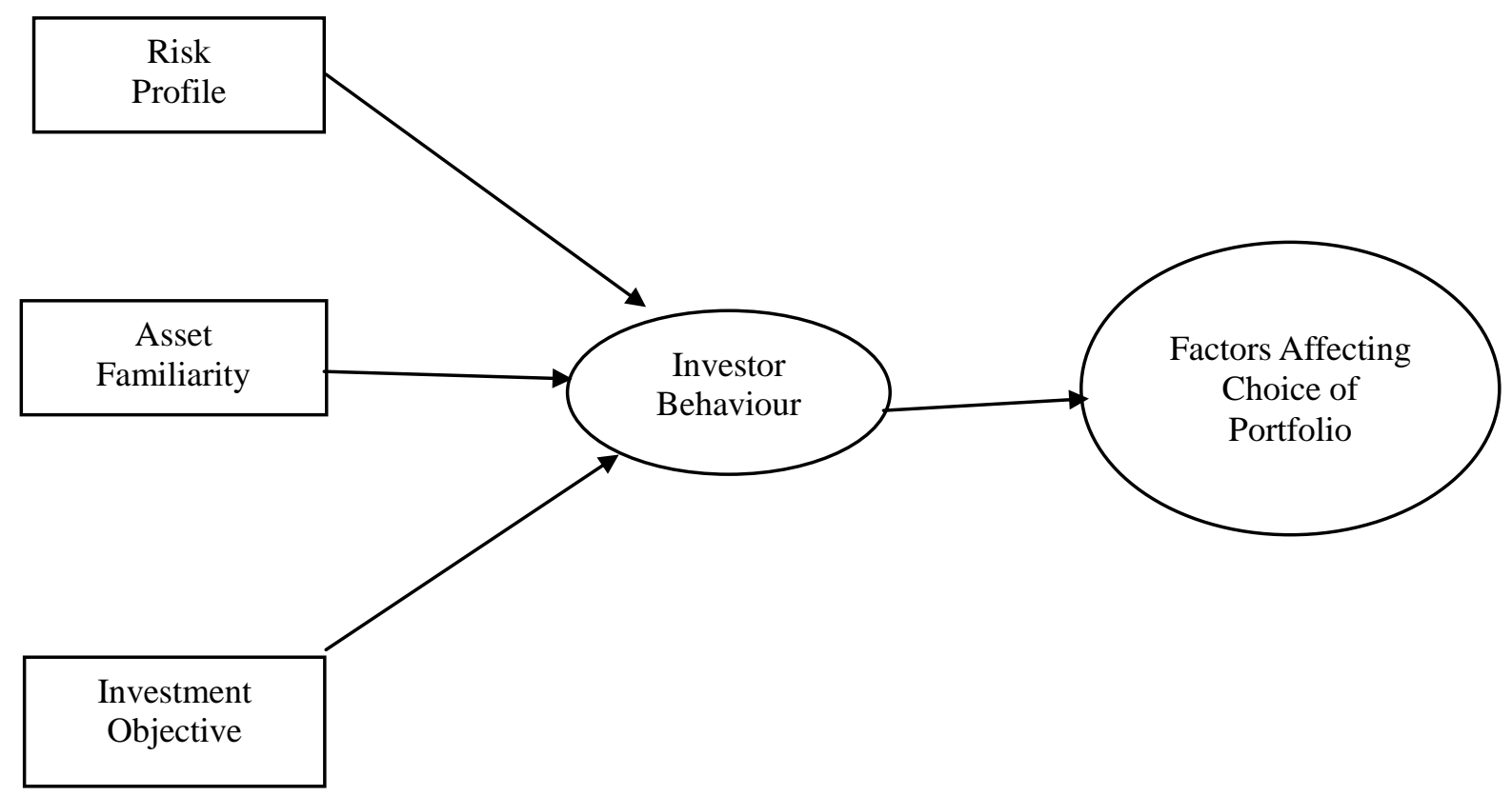

Figure 1. Research framework

\subsection{Data Collection}

Around 250 self-administered questionnaires were used to gather data from the respondents. A questionnaire using a 5-point Likert scale (i.e. a scale with 1 indicating "strong disagreement" and 5 indicating "strong agreement") was used to collect data for all the variables of the research model. All the instruments were adapted from the previous literature and modified to measure the performance.

A total of 206 questionnaires were received and used for this analysis. The next section presents the assessment of the goodness of the measures of these constructs regarding their validity and reliability within the research framework. A detailed distribution of the characteristics of the respondents and their investment objective is depicted in the table below.

Table 1. Demography of the respondents $(n=206)$ concerning investment objective, income group and age

\begin{tabular}{llll}
\hline Item & Measure & Frequency & Percentage \\
\hline \multirow{3}{*}{ Investment Objective } & Building a financial buffer & 38 & $18 \%$ \\
& Capital growth & 78 & $38 \%$ \\
& Future needs & 58 & $28 \%$ \\
& Speculation & 32 & $16 \%$ \\
\hline \multirow{3}{*}{ Income Group } & 3000 to 10000 USD & 99 & $48 \%$ \\
& Less than 3000 USD & 40 & $19 \%$ \\
& More than 10000 USD & 31 & $15 \%$ \\
Age & Not working & 36 & $17 \%$ \\
\hline & Up to 20 & 22 & $11 \%$ \\
& $21-35$ & 84 & $41 \%$ \\
& $36-50$ & 79 & $38 \%$ \\
& Above 50 & 21 & $10 \%$ \\
\hline
\end{tabular}




\subsection{Data Analysis}

Primary data were collected through the online surveys and modelled. For the data modelling, Smart PLS (PL-SEM), which is a structural equation modelling tool that helps in modelling variance-based structural equations for postulating hypotheses and in turn for making the research framework, was used (Dijkstra and Henseler, 2015). The analysis got performed in two steps. The first phase was the structural model, which involved estimation through modelling, and in the second phase, the reliability and validity were used to measure the best model fit (Dijkstra and Wilson, 2012).

The Smart PLS 2.0M3 software (Ringle, Wende and Will, 2005) was used for the PLS (partial least square) technique, to validate the measurements and to test the hypotheses. The PLS technique follows a component-based approach to model estimation. It is best suited to testing complex structural models. Since the PLS technique does not impose any normality requirements on the data, it was chosen. The SmartPLS 2.0 M3 software \{http://smartpls.com (Ringle et al., 2005)\} was used for path modelling with latent variables. The tool is best known for measuring the validity and reliability of constructs. Besides that, bootstrapping was applied to 207 cases (sample size) to generate the standard error of the estimation and $t$-values. The Smart PLS software uses the PLS technique to examine theory and measures simultaneously (Hulland, 1999).

\subsection{Goodness of Measures}

The main criteria for testing the goodness of measures are validity and reliability. The reliability test shows how consistent the measures are, irrespective of the concept being measured, whereas the validity test shows how well an instrument measures the particular concept that it is intended to measure (Sekaran and Bougie, 2010).

\subsection{Construct Validity}

The construct validity test shows how well the results obtained from the use of the measure fit the theories around which the test is designed (Sekaran and Bougie, 2010). In Table 2 below, we can observe that all the items measuring a particular construct are loaded highly on that construct while they are lower on the other constructs, thus confirming construct validity.

Table 2. Loadings and cross-loadings

\begin{tabular}{llllll}
\hline & Asset & Investor & Investment & Risk \\
& Familiarity & Behaviour & Objective & $\begin{array}{l}\text { Choice } \\
\text { Profile }\end{array}$ & Portfolio \\
\hline AssetF1 & $\mathbf{0 . 6 6 3 3}$ & 0.2548 & 0.2537 & 0.4661 & 0.3648 \\
AssetF2 & $\mathbf{0 . 8 6 0 3}$ & 0.4786 & 0.3916 & 0.4865 & 0.4219 \\
AssetF3 & $\mathbf{0 . 8 7 0 4}$ & 0.5018 & 0.3522 & 0.5231 & 0.3830 \\
AssetF4 & $\mathbf{0 . 7 9 3 9}$ & 0.4527 & 0.3721 & 0.4078 & 0.2646 \\
InvestorB1 & 0.4070 & $\mathbf{0 . 7 8 4 6}$ & 0.4273 & 0.2657 & 0.3827 \\
InvestorB2 & 0.5127 & $\mathbf{0 . 8 7 6 6}$ & 0.4766 & 0.3471 & 0.3209 \\
InvestorB4 & 0.4540 & $\mathbf{0 . 8 6 2 3}$ & 0.5603 & 0.3970 & 0.2897 \\
InvestmentO2 & 0.2790 & 0.3534 & $\mathbf{0 . 7 4 6 8}$ & 0.3712 & 0.3072 \\
InvestmentO3 & 0.3494 & 0.5132 & $\mathbf{0 . 8 6 1 5}$ & 0.4307 & 0.2642 \\
InvestmentO4 & 0.3937 & 0.5006 & $\mathbf{0 . 7 7 7 0}$ & 0.3967 & 0.2213 \\
PortfolioP1 & 0.4918 & 0.3163 & 0.3499 & $\mathbf{0 . 8 4 9 7}$ & 0.2676 \\
PortfolioP2 & 0.5301 & 0.3956 & 0.4885 & $\mathbf{0 . 9 0 3 2}$ & 0.2965 \\
PortfolioP3 & 0.4201 & 0.2454 & 0.4547 & $\mathbf{0 . 7 8 2 0}$ & 0.3437 \\
PortfolioP4 & 0.5020 & 0.3756 & 0.4102 & $\mathbf{0 . 8 3 7 0}$ & 0.3080 \\
RiskP1 & 0.3552 & 0.3611 & 0.2627 & 0.2587 & $\mathbf{0 . 8 6 9 7}$ \\
RiskP2 & 0.4157 & 0.3615 & 0.3570 & 0.3327 & $\mathbf{0 . 8 5 7 6}$ \\
RiskP3 & 0.2998 & 0.1711 & 0.1090 & 0.3043 & $\mathbf{0 . 7 2 7 0}$ \\
\hline
\end{tabular}

Bold values are loadings for items that are above the recommended value of 0.5 . 


\subsection{Convergent Validity}

When testing the convergent validity, we expect each item's loading on its underlying construct to be above 0.50 (Hair et al., 2010). We also want the average variance extracted (AVE) for each construct to be above the minimum recommended value of 0.50 (Bagozzi and Yi, 1988; Dillon and Goldstein, 1984; Fornell and Larcker, 1981). As observed in the following Table 3, the AVE values are above 0.63. It is also apparent that each item's loading constructs are above 0.6, as shown in Table 4. These two tests prove that the convergent validity has given satisfactory results for the measurement model.

Table 3. Results of the measurement model

\begin{tabular}{lllll}
\hline Model Construct & Measurement Item & Loading & $\begin{array}{l}\text { Composite } \\
\text { Reliability }\end{array}$ & AVE \\
\hline Asset Familiarity & AssetF1 & 0.6633 & 0.8765 & 0.642 \\
& AssetF2 & 0.8603 & & \\
& AssetF3 & 0.8704 & & \\
& AssetF4 & 0.7939 & & 0.7092 \\
Investor Behaviour & InvestorB1 & 0.7846 & 0.8795 & \\
& InvestorB2 & 0.8766 & & 0.6346 \\
Investment Objective & InvestorB4 & 0.8623 & & \multirow{2}{*}{0.6735} \\
& InvestmentO2 & 0.7468 & 0.8385 & \\
Risk Profile & InvestmentO3 & 0.8615 & & \multirow{2}{*}{0.7124} \\
& InvestmentO4 & 0.777 & & \\
& RiskP1 & 0.8697 & 0.8601 & \\
Choice of Portfolio & RiskP2 & 0.8576 & & \\
& RiskP3 & 0.727 & & \\
& PortfolioP1 & 0.8497 & 0.9081 & \\
& PortfolioP2 & 0.9032 & & \\
& PortfolioP3 & 0.782 & & \\
& PortfolioP4 & 0.837 & & \\
\hline
\end{tabular}

a. Composite reliability $(\mathrm{CR})=$ (square of the summation of the factor loadings) / \{ (square of the summation of the factor loadings) + (square of the summation of the error variances) $\}$

b. Average variance extracted $(\mathrm{AVE})=$ (summation of the square of the factor loadings) / \{ (summation of the square of the factor loadings) + (summation of the error variances) $\}$

Table 4 below summarises the results of the measurement model, which shows that all the five constructs - asset familiarity, investor behaviour, investment objective, risk profile and choice of portfolio - are valid measures of their respective constructs (Chow and Chan, 2008). 
Table 4. Summary results of the model constructs

\begin{tabular}{llll}
\hline Model Construct & Measurement Item & Loading & T-value \\
\hline Asset Familiarity & AssetF1 & 0.6633 & 10.8841 \\
& AssetF2 & 0.8603 & 40.0894 \\
AssetF3 & 0.8704 & 39.6753 \\
Investor Behaviour & AssetF4 & 0.7939 & 26.3010 \\
& InvestorB1 & 0.7846 & 16.9198 \\
& InvestorB2 & 0.8766 & 40.0316 \\
Investment Objective & InvestorB4 & 0.8623 & 42.9804 \\
& InvestmentO2 & 0.7468 & 13.7301 \\
& InvestmentO3 & 0.8615 & 29.6035 \\
Risk Profile & InvestmentO4 & 0.777 & 20.5283 \\
& RiskP1 & 0.8697 & 24.9969 \\
& RiskP2 & 0.8576 & 54.9376 \\
Choice of Portfolio & RiskP3 & 0.727 & 13.3934 \\
& PortfolioP1 & 0.8497 & 30.8704 \\
& PortfolioP2 & 0.9032 & 30.7478 \\
& PortfolioP3 & 0.782 & 29.1945 \\
& PortfolioP4 & 0.837 & 10.4648
\end{tabular}

\subsection{Discriminant Validity}

Discriminant validity indicates the extent to which the measures in a model are distinct from other steps in the same model. In the PLS context, the criterion for discriminant validity is that a construct should share more variance with its measures than it shares with other constructs in the given model (Hulland, 1999). The discriminant validity was examined by testing the correlations between the measures of potentially overlapping constructs, which must be different from unity (Anderson and Gerbing, 1988). Also as shown in Table 5 below, the square of the correlations for each construct is less than the average variance extracted by the indicators measuring that construct, which indicates adequate discriminant validity. In total the measurement model demonstrated the adequate convergent validity and discriminant validity.

Table 5. Discriminant validity of the constructs

\begin{tabular}{lrllll}
\hline Constructs & \multicolumn{1}{c}{1} & 2 & 3 & 4 & 5 \\
\hline 1. Asset Familiarity & $\mathbf{0 . 8 0 1 2}$ & & & & \\
2. Investor Behaviour & 0.5452 & $\mathbf{0 . 8 4 2 1}$ & & & \\
3. Investment Objective & 0.4338 & 0.5834 & $\mathbf{0 . 7 9 6 6}$ & & \\
4. Risk Profile & 0.5801 & 0.4043 & 0.503 & $\mathbf{0 . 8 4 4}$ & \\
5. Choice of Portfolio & 0.4407 & 0.3879 & 0.3241 & 0.355 & $\mathbf{0 . 8 2 0 7}$
\end{tabular}

Diagonals (in bold) represent the average variance extracted, while the other entries represent the squared correlations.

\subsection{Reliability Analysis}

The Cronbach's alpha coefficient was used to assess the inter-item consistency of our

measures. Table 6, as given below, summarises the loadings and alpha values. As observed from the table, all the alpha values are above 0.6, as suggested by Nunnally and Berstein (1994). The composite reliability values are in the range of 0.8385 to 0.9081 . Interpreted like a Cronbach's alpha for the internal consistency reliability estimate, the composite reliability of 0.70 or greater is considered acceptable (Fornell and Larcker, 1981). Thus, we can conclude that the measurements are reliable. 
Table 6. Result of the reliability test

\begin{tabular}{|c|c|c|c|c|}
\hline Constructs & Measurement Items & Cronbach's $\alpha$ & $\begin{array}{l}\text { Loading } \\
\text { Range }\end{array}$ & $\begin{array}{l}\text { Number } \\
\text { of Items }\end{array}$ \\
\hline $\begin{array}{l}\text { Asset } \\
\text { Familiarity }\end{array}$ & $\begin{array}{l}\text { AssetF1, AssetF2, AssetF3, } \\
\text { AssetF4 }\end{array}$ & 0.8146 & $\begin{array}{l}0.6633-0.870 \\
4\end{array}$ & $4(4)$ \\
\hline $\begin{array}{l}\text { Investor } \\
\text { Behaviour }\end{array}$ & $\begin{array}{l}\text { InvestorB1, } \\
\text { InvestorB4 }\end{array}$ & 0.7947 & $\begin{array}{l}0.7846-0.876 \\
6\end{array}$ & $3(4)$ \\
\hline $\begin{array}{l}\text { Investment } \\
\text { Objective }\end{array}$ & $\begin{array}{l}\text { InvestmentO2, InvestmentO3, } \\
\text { InvestmentO4 }\end{array}$ & 0.7146 & $\begin{array}{l}0.7468-0.861 \\
5\end{array}$ & $3(3)$ \\
\hline Risk Profile & RiskP1, RiskP2, RiskP3 & 0.8664 & $0.727-0.8697$ & $3(4)$ \\
\hline $\begin{array}{l}\text { Choice } \quad \text { of } \\
\text { Portfolio }\end{array}$ & $\begin{array}{l}\text { PortfolioP1, } \quad \text { PortfolioP2, } \\
\text { PortfolioP3, PortfolioP4 }\end{array}$ & 0.7688 & $0.782-0.9032$ & $4(4)$ \\
\hline
\end{tabular}

Final item numbers (initial numbers)

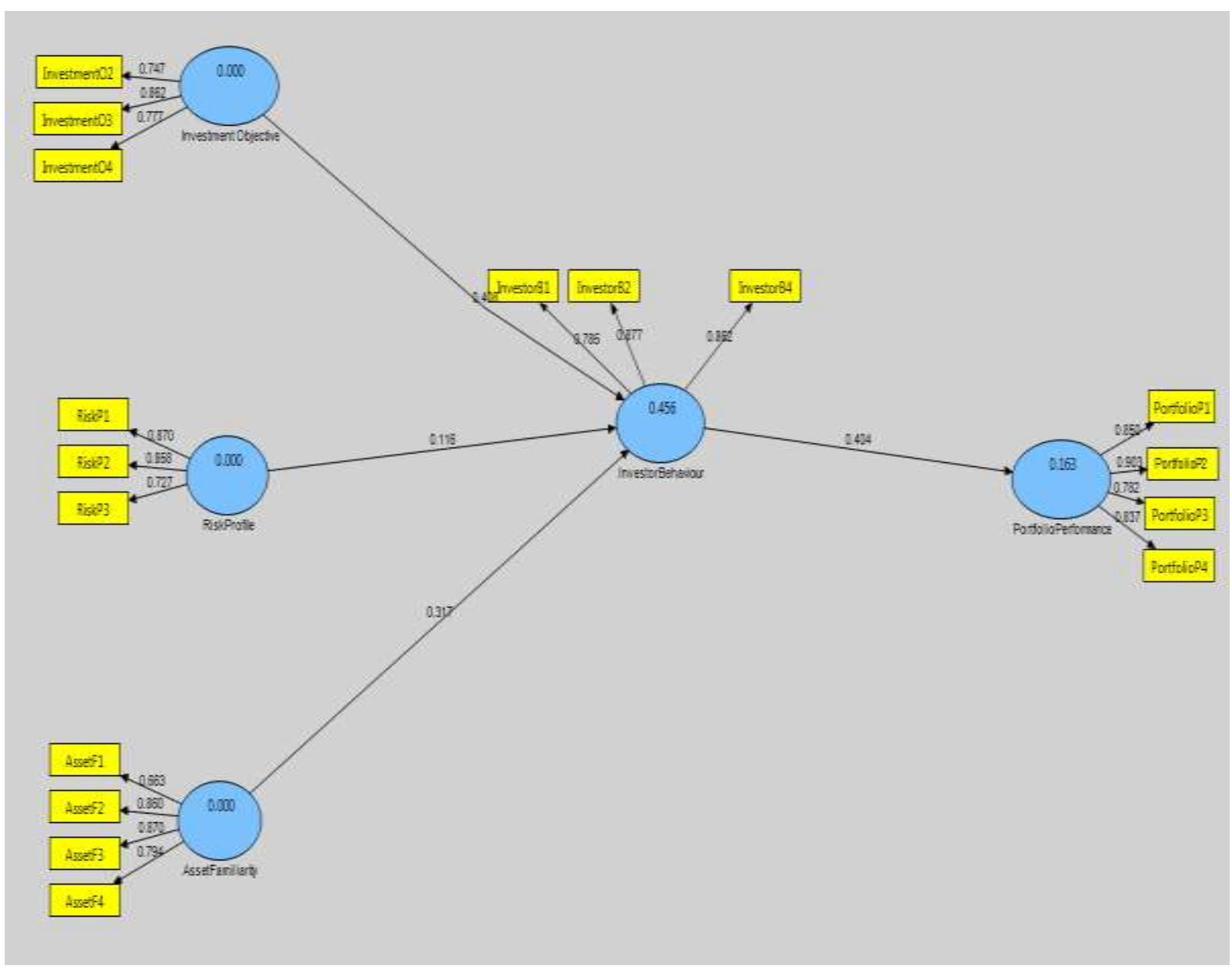

Figure 2. Results of the path analysis

Summary of the hypotheses tests (path coefficients and hypothesis testing)

Significance values

$\begin{array}{ll}\mathrm{P}<0.1 & 1.652 \\ \mathrm{P}<0.05 & 1.971 \\ \mathrm{P}<0.01 & 2.599\end{array}$


This research generated seven hypotheses, and the reliability of these hypotheses was verified against the t-values of the independent variables on the dependent variables. This is shown above.

Table 7. Path coefficients and hypothesis testing

\begin{tabular}{|c|c|c|c|c|c|}
\hline $\begin{array}{l}\text { Hypothesis } \\
\text { No. }\end{array}$ & Hypothesis (Direction) & & $\begin{array}{l}\text { Path } \\
\text { Coefficient }(\beta)\end{array}$ & T-value & Supported \\
\hline $\mathrm{H} 1$ & $\begin{array}{l}\text { Asset Familiarity } \\
\text { Investor Behaviour }\end{array}$ & $\rightarrow$ & 0.317 & 5.5113 & Yes \\
\hline $\mathrm{H} 2$ & $\begin{array}{l}\text { Investment Objective } \\
\text { Investor Behaviour }\end{array}$ & $\rightarrow$ & 0.4083 & 4.8641 & Yes \\
\hline $\mathrm{H} 3$ & $\begin{array}{l}\text { Risk Profile -> Invest } \\
\text { Behaviour }\end{array}$ & & 0.115 & 1.585 & No \\
\hline $\mathrm{H} 4$ & $\begin{array}{l}\text { Investor Behaviour } \\
\text { Choice of Portfolio }\end{array}$ & $\rightarrow$ & 0.4043 & 5.9047 & Yes \\
\hline H5 & $\begin{array}{l}\text { Asset Familiarity } \\
\text { Investor Behaviour } \\
\text { Choice of Portfolio }\end{array}$ & $\overrightarrow{->}$ & & 4.0274 & Yes \\
\hline H6 & $\begin{array}{l}\text { Investment Objective } \\
\text { Investor Behaviour } \\
\text { Choice of Portfolio }\end{array}$ & $\begin{array}{l}-> \\
->\end{array}$ & & 3.752 & Yes \\
\hline $\mathrm{H} 7$ & $\begin{array}{l}\text { Risk Profile } \rightarrow \text { Invest } \\
\text { Behaviour-> Choice } \\
\text { Portfolio }\end{array}$ & stor & & 1.5323 & No \\
\hline
\end{tabular}

\section{Research Findings}

Next, we proceed with the path analysis to test the four hypotheses generated. Figure 2 and Table 7 present the results. The $\mathrm{R}^{2}$ value is 0.456 , suggesting that $45.6 \%$ of the variance in the extent of investor behaviour can be explained by the asset familiarity, investment objective and risk profile of the individual investors.

The first hypothesis, H1, examines the impact familiarity of the asset on the individual investor behaviour. Asset familiarity shows a strong influence, that is, (t-value $=5.5113, \quad \mathrm{CI}>99 \%)$, and thus $\mathrm{H} 1(\beta=0.317, \mathrm{p}<0.01)$ is accepted. It indicates that financial knowledge or understanding about a particular investment product has a significant impact on an investor's behaviour and he is more likely to invest in those products or assets. It is a new finding compared with an earlier study (i.e. Frijns, Koellen and Lehnert, 2006), which found no clear evidence of asset familiarity's effect on investors' investment behaviour and their portfolio choices.

The second hypothesis, $\mathrm{H} 2$, highlights the effect of the investment objective on the individual investor behaviour. The effect of the investment objective is found to be significant ( $\mathrm{t}$-value $=4.8641, \mathrm{CI}>99 \%)$. Thus, H2 ( $\beta=0.4083$, $\mathrm{p}<0.01)$ is accepted. It indicates that the investment objective of the individual has a major effect on his investor behaviour. This is by some other findings (e.g. Shah, Zanwar, and Deshmukh, 2011), which showed that life cycle stages have a significant relationship with investment objectives.

The third hypothesis, H3, tested the impact of individuals' risk profile on their investment behaviour. The risk profile is not found to be significant in influencing the investor behaviour ( $\mathrm{t}$-value $=1.585$ ), and thus $\mathrm{H} 3(\beta=0.115)$ is rejected. This finding is in contrast to some earlier studies (e.g. Nosic and Weber, 2010), which found that behavioural biases, such as overconfidence and excessive optimism, significantly affect investor behaviour.

The fourth hypothesis, $\mathrm{H} 4$, tested the effect of overall individual investor behaviour on the choice of the portfolio and thereby its performance. The effect of investor behaviour is again found to be significant ( $t$-value $=5.9047, \mathrm{CI}>$ $99 \%)$, and thus $\mathrm{H} 4(\beta=0.4043, \mathrm{p}<0.01)$ is supported.

$\mathrm{H} 4$ was also supported by the $\mathrm{R}^{2}$ square value of 0.363 , which suggests that $36.3 \%$ of the variance in portfolio choice can be explained by the extent of investor behaviour, and the positive relationship $(\beta=0.4043, p<0.01)$ between the extent of investor behaviour and the choice of the portfolio. This is in accordance with some other findings (e.g. Hoffmann et al., 2010), which showed that investor behaviour has a significant relationship with the portfolio and 
that investors driven by objectives related to speculation have higher aspirations and turnover, take more risk, judge themselves to be more advanced and underperform relative to investors driven by the need to build a financial buffer or save for retirement.

To test the mediation effect, the Sobel test was performed. It shows whether a mediator variable significantly carries the influence of an independent variable to a dependent variable, that is, whether the indirect effect of the independent variable on the dependent variable through the mediator variable is significant. The results indicate that the extent of investor behaviour mediates the relationship between the investment objective and the choice of the portfolio as well as the relationship between the asset familiarity and the choice of the portfolio. The risk profile has neither a direct effect nor an indirect effect on the extent of investor behaviour. Therefore, hypotheses H5 and H6 are accepted, but $\mathrm{H} 7$ is rejected.

\section{Limitations and Scope for Future Research}

This paper has its boundaries in that different factors may influence investor behaviour, giving rise to complexities in measuring particular relationships. As we know from behavioural science, human behaviour is affected by the emotional processes involved, which influence the decision-making process to vary degrees. It may also be of worth to find the exact investment choices by individual investors, and the portfolio returns to understand their investment portfolio performance. Also, Singapore being an island economy with a significant number of foreigners who may have major investments within their native country, it may be of further interest to understand their investment pattern exclusively in investments made in Singapore.

\section{Conclusions}

This study focused on the factors affecting individual investors' behaviour and their portfolio. It supports the conventional views on the influence of the independent variables of investment objective, risk profile and asset familiarity on the perceived extent of investor behaviour using the partial least square (PLS) technique in testing the hypotheses. It also examined how this perceived extent of investor behaviour may predict the individual choice of portfolio and its performance. As the extent of investor behaviour is also an intervening variable in the study, an attempt was made to assess its mediating effect on the investment objective, risk profile and asset familiarity in the overall model. The paper also examined the goodness of the measures, which was assessed by looking at the validity and reliability of the measures using the PLS approach. The results showed that the measures used exhibited both convergent and discriminant validity. Next, we proceeded to assess the reliability of the measures by looking at the Cronbach's alpha values and composite reliability values. Both the Cronbach's alpha values and composite reliability values were on a par with the criteria set up by other established researchers. As such, the measures in the model were shown to be reliable.

The findings of this paper are that the investment objective and asset familiarity exert an impact on investor behaviour, with asset familiarity having the strongest impact. Investor behaviour, in turn, influences the choice of a portfolio of the investors. As we stated earlier, although this is true, the hypothesis has not been tested in an island economy like Singapore. This study hence provides useful insights and information regarding the factors that investment planners, financial advisers and individuals need to consider to improve their choice of the portfolio and its performance. From the findings, it is clear that the investment objective and asset familiarity play a vital role in the choice of the portfolio. This shows that asset familiarity introduces the bias and creates the confidence that the returns are guaranteed. This may prevent individuals from diversifying their portfolio, and hence there is a need to create awareness. Some people may have a long-term objective, like investing for retirement, child education and so on, while others may save for short-term objectives, like buying a house or holiday, which will influence the type of investments that they choose and hence their portfolio returns.

\section{Acknowledgements}

For language editing and proof reading, service was rendered by PRS proof reading service UK. http://www.proof-reading-service.com/en/

\section{References}

Anderson, J. C., \& Gerbing, S. W. (1988). Structural equation modeling in practice:A review and recommended two-step approach. Psychological Bulletin, 103(3), 411-423. https://doi.org/10.1037/0033-2909.103.3.411

Bagozzi, R. P., \& Yi, Y. (1988). On the evaluation of structural equation models. Journalof the Academy of Marketing Science, 16(1), 74-94. https://doi.org/10.1007/BF02723327

Baker, H. Kent, Michael B. Hargrove and John A. Haslem. (1977). An empirical analysis of the risk-return 
preferences of individual investors. Journal of Financial and Quantitative Analysis, 12(3), 377-389. https://doi.org/10.2307/2330541

Barclay, D.W., R. Thompson \& C. Higgins. (1995). The partial least squares (PLS) approach to causal modeling: Personal computer adoption and use: An illustration. Technology Studies, 2(2), 285-309.

Boyle, Phelim P., Lorenzo Garlappi, Raman Uppal \& Tan Wang. (2009). Keynes Meets Markowitz: The Tradeoff between Familiarity and Diversification. AFA Atlanta Meetings Paper. https://doi.org/10.2139/ssrn.1365014

Chandra, Abhijeet \& Ravinder Kumar. (2012). Factors influencing Indian individual investor behaviour: Survey evidence. Indian Institute of Management Calcutta, Decision, 39(3), 141-167. https://doi.org/10.2139/ssrn.2029642

Charness, Gary \& Uri Gneezy. (2010). Portfolio choice and risk attitudes: An experiment. Western Economic Association International, 48(1), 133-146. https://doi.org/10.1111/j.1465-7295.2009.00219.x

Chow, W.S. \& L.S. Chan. (2008). Social network, social trust and shared goals in organizational knowledge sharing. Information \& Management, 45(7), 458-465. https://doi.org/10.1016/j.im.2008.06.007

Cohen, Gil \& Andrey Kudryavtsev. (2012). Investor rationality and financial decisions. Journal of Behavioral Finance, 13, 38-50. https://doi.org/10.1080/15427560.2012.653020

Cohn, Richard A., Wilbur G. Lewellen, Ronald C. Lease \& Gary G. Schlarbaum. (1975). Individual investor risk aversion and investment portfolio composition. Journal of Finance, 30(2), 605-620. https://doi.org/10.1111/j.1540-6261.1975.tb01834.x

Compeau, D.R., C.A. Higgins \& S. Huff. (1999). Social cognitive theory and individual reactions to computing technology: A longitudinal-study. MIS Quarterly, 23(2), 145-158. https://doi.org/10.2307/249749

Daniela, Laura. (2011). The saving and investing consumer behavior analyses on the Romanian financial market. Annals of the University of Oradea. Economic Sciences, 2, 798-804.

Dillon, W. R., \& Goldstein, M. (1984). Multivariate analysis: Methods and applications. New York: Wiley.

Dorny, Daniel \& Gur Hubermanz. (2005). Talk and action: What individual investors say and what they do. Review of Finance, 9(4), 437-481. https://doi.org/10.1007/s10679-005-4997-z

Durand, Robert B., Rick Newby, Leila Peggs \& Michelle Siekierka. (2013). Personality. Journal of Behavioral Finance, 14, 116-133. https://doi.org/10.1080/15427560.2013.791294

Evans, Jeffrey L. (2004). Wealthy investor attitudes, expectations, and behaviors toward risk and return. Journal of Portfolio Management, 7(1), 12-18. https://doi.org/10.3905/jwm.2004.412350

Fagereng, Andreas and Gottlieb, Charles \& Guiso, Luigi. (2015). Asset Market Participation and Portfolio Choice Over the Life-Cycle (2015). SAFE Working Paper No. 115. Available at SSRN: http://ssrn.com/abstract $=2660160$

Fenghua, W.E.N. (1981). Characteristics of investors' risk preference for stock markets. Economic Computation \& Economic Cybernetics Studies \& Research, 3(48), 235-254.

Foad, Hisham. (2010). Familiarity bias. Behavioral Finance: Investors, Corporations, and Markets. Wiley. Chapter 15. https://doi.org/10.1002/9781118258415.ch15

Foad, Hisham S. (2008). Familiarity breeds investment: Immigration and equity home bias. https://doi.org/10.2139/ssrn.1107647

Fornell, C. \& D.F. Larcker. (1981). Evaluating structural equation models with unobservable variables and measurement error. Journal of Marketing Research, 18(1), 39-50. https://doi.org/10.2307/3151312

Frijns, Bart, Esther Koellen \& Thorsten Lehnert. (2006). On the determinants of portfolio choice. Journal of Economic Behavior \& Organization, 7, 77-92.

Furrer, O., B. Tjemkes \& J. Henseler. (2012). A model of response strategies in strategic alliances: A PLS analysis of a circumplex structure. Long Range Planning, 45(5-6), 424-450. https://doi.org/10.1016/j.1rp.2012.10.003

Hair, J.F., W.C. Black, B.J. Babin \& R.E. Anderson. (2010). Multivariate Data Analysis. Prentice-Hall, Upper Saddle River.

Hibbert, Ann Marie. (2012). The role of financial education in the management of retirement savings. Journal of Behavioral Finance, 13, 299-307. https://doi.org/10.1080/15427560.2012.735727 
Hibbert, Ann Marie, Edward R. Lawrence \& Arun J. Prakash. (2012). Can diversification be learned? Journal of Behavioral Finance, 13, 38-50. https://doi.org/10.1080/15427560.2012.654547

Hoffmann, Arvid O. I., Hersh Shefrin \& Joost M. E. Pennings. (2010). Behavioral portfolio analysis of individual investors. https://doi.org/10.2139/ssrn.1629786

Hulland, J. (1999). Use of partial least squares (PLS), Strategic management research:A review of four recent studies. $\begin{array}{llll}\text { Strategic } & \text { Management } & \text { Journal, } & 20(4),\end{array}$ https://doi.org/10.1002/(SICI)1097-0266(199902)20:2<195::AID-SMJ13>3.0.CO;2-7

Ivković, Zoran, Clemens Sialm \& Scott Weisbenner. (2006). Portfolio concentration and the performance of individual investors. Journal of Financial and Quantitative Analysis.

Jain, Dhiraj \& Mandot, Niklhil. (2012). Impact of Demographic Factors on Investment Decision of Investors in Rajasthan. International Refereed Research Journal, 2(3), 81-92

Jiang, R. J., Tao, Q. T., \& Santoro, M. D. (2010). Alliance portfolio diversity and firm performance. Strategic Management Journal, 31(10), 1136-1144. https://doi.org/10.1002/smj.869

Journal of Risk Management in Financial Institutions, 1(4): 416-429

Kahneman, Daniel \& Tversky, Amos. (1979). Prospect Theory: An Analysis of Decision under Risk. Econometrica, 47(2), 263-291. https://doi.org/10.2307/1914185

Kaur, Mandeep \& Tina Vohra. (2012). Understanding individual investor's behavior - A review of empirical evidences. Pacific Business Review International, 5(6), 10-18.

Kavitha, C. (2013). Determinants of retail investor's behaviour and its impact on investment decision. International Journal of Global Business Management \& Research, 2(1), 75-85.

Lindblom, Ted, Taylan Mavruk \& Stefan Sjögren. (2013). Individual investors' portfolio choice and birthplace bias. Available at SSRN: http://ssrn.com/abstract=2129290

Maheswari, P. (2014). Role of planning in the financial decision making of individuals. International Journal of Business and Administration Research Review, 3(6), 88-94.

Markowitz, H. (1952). Portfolio Selection. The Journal of Finance, 7(1), 77-91. https://doi.org/10.1111/j.1540-6261.1952.tb01525.x

Marosi, James. (2005). Investment commentary. Grand Rapids Business Journal, 23.

Mehta, Kiran \& Renuka Sharma. (2015). Individual investors' behavior: In demographical backdrop. SCMS Journal of Indian Management, 12(3), 25-36.

Mohamed, Ezzeddine Ben, Nizar Hachicha \& Abdelfatteh Bouri. (2012). The portfolio choice in emergent markets: A rational or a behavioral decision: A cognitive answer. European Journal of Business and Management, 4(2), $11-21$.

Nosic, Alen \& Martin Weber. (2010). How riskily do I invest: The role of risk attitudes, risk perceptions, and overconfidence. Decision Analysis, 7(3), 282-301. https://doi.org/10.1287/deca.1100.0178

Nunnally, J. \& I. Berstein. (1994). Psychometric Theory. McGraw-Hill, New York.

Obamuyi, Tomola Marshal. (2013). Factors influencing investment decisions in capital market: A study of individual investors in Nigeria. Organizations \& Markets in Emerging Economies, 4(1), 141-161.

Olsen, Robert. (2012). Trust: The underappreciated investment risk attribute. Journal of Behavioral Finance, 13, 308-313. https://doi.org/10.1080/15427560.2012.735728

Örerler, Esin Okay \& Dicle Taşpınar. (2006). Utility function and risk taking: An experiment. Journal of American Academy of Business, Cambridge, 9(2), 167-174.

Pandit, Ameet \& Ken Yeoh. (2014). Psychological tendencies in an emerging capital market: A study of individual investors in India. Journal of Developing Areas, 48(3), 129-148. https://doi.org/10.1353/jda.2014.0049

Peñaranda, F. (2016). Understanding portfolio efficiency with conditioning information. Journal of Financial and Quantitative Analysis, 51(03), 985-1011. https://doi.org/10.1017/S0022109016000338

Peteros, Randall \& John Maleyeff. (2013). Application of behavioural finance concepts to investment decision-making. International Journal of Management, 30(1), Part 2. 
Pfeiffer, S. (2016). Learning How Not to Lose. Journal of Financial Service Professionals, 70(4), 20-23.

Praba, R. Suyam. (2011). Investors' decision making process and pattern of investments - A study of individual investors in Coimbatore. SIES Journal of Management, 7(2), 1-12.

Rannou, Yves. (2008). Measuring investor sentiment and behaviour to gauge financial risk.

Ricciardi, Victor \& Helen K. Simon. (2000). What is behavioral finance? Business, Education and Technology Journal, 2(2), 1-9.

Ringle, C. M., Wende, S., \& Will, A. (2005). SmartPLS 2.0 M3 (beta). University of Hamburg. www.smartpls.de

Sahi, Shalini Kalra, Ashok Pratap Arora \& Nand Dhameja. (2013). An exploratory inquiry into the psychological biases in financial investment behavior. Journal of Behavioral Finance, 14, 94-103. https://doi.org/10.1080/15427560.2013.790387

Sekaran, U. \& R. Bougie. (2010). Research Methods for Business: A Skill Building Approach. Wiley, UK.

Selvi, T. Tamil. (2015). Investor's attitude towards investment avenues. International Journal of Management and Commerce Innovations, 3(1), 717-722.

Shah, Vrushali, Priyanka Zanwar \& Pratibha Deshmukh. (2011). Stages in life cycle and investment pattern of rural investors - A case study. BVIMR Management Edge, 4(2), 48-59.

Siebenmorgen, Niklas \& Martin Weber. (2004). The influence of different investment horizons on risk behaviour. Journal of Behavioural Finance, 5(2), 75-90. https://doi.org/10.1207/s15427579jpfm0502_2

Sobel Test Calculator for the Significance of Mediation. http://www.danielsoper.com/statcalc/calculator.aspx?id=31

Tekçe, Bülent \& Yapı Kredi Bank. (2015). What factors affect behavioral biases? Evidence from Turkish individual stock investors. Research in International Business and Finance, 37, 515-526. https://doi.org/10.1016/j.ribaf.2015.11.017

Veld-Merkoulova, Yulia V. (2009). Investment horizon, labor income, and portfolio choice of private investors. https://doi.org/10.2139/ssrn.1326348

Wang, Alex. (2009). Interplay of investors' financial knowledge and risk taking. Journal of Behavioral Finance, 10(4), 204-213. https://doi.org/10.1080/15427560903369292 